\title{
Ramucirumab - egy új gyógyszer az onkológiában
}

\author{
Telekes András dr. ${ }^{1,2}$ - Deme Dániel ${ }^{2}$ \\ ${ }^{1}$ Bajcsy-Zsilinszky Kórház, Onkológia, Budapest \\ ${ }^{2}$ Szent Lázár Megyei Kórház, Onkológia, Salgótarján
}

\begin{abstract}
A ramucirumab egy humanizált vascularis endothelialis növekedési faktor receptor-2 elleni monoklonális antitest, amely megakadályozza a vascularis endothelialis növekedési faktor-A, -C és -D ligandok kötődését. Gátolja továbbá a p44/p42 mitogén aktiválta proteinkinázok ligand által stimulált aktivációját, ezzel neutralizálva a humán endothelsejtek ligand által indukált proliferációját és migrációját. A REGARD (Ramucirumab monotherapy for previously treated advanced gastric or gastro-oesophageal junction adenocarcinoma) és a RAINBOW (Ramucirumab plus paclitaxel versus placebo plus paclitaxel in patients with previously treated advanced gastric or gastro-oesophageal junction adenocarcinoma) vizsgálatok eredményei alapján a ramucirumab befogadásra került másodvonalbeli kezelésként, mint monoterápia és paclitaxellel történő kombinációban a lokálisan recidiváló és nem reszekábilis vagy metasztatizáló gyomorrákban (beleértve a gastrooesophagealis junctio adenocarcinomáját is). Az eddigi adatok alapján előrehaladott szolid daganatokban szenvedő betegeknél a progressziómentes túlélést és a teljes túlélést megnyújthatja a ramucirumab adása, de emellett az összes nemkívánatos esemény kockázatát is megemelheti (fáradtság, neutropenia, vérzés, hányinger, stomatitis). A szerzők áttekintik a ramucirumabbal végzett vizsgálatokat. Orv. Hetil., 2016, $157(40), 1587-1594$.
\end{abstract}

Kulcsszavak: ramucirumab, humanizált monoklonális antitest, gyomorrák, szolid daganatok

\section{Ramucirumab - a new anticancer agent}

Ramucirumab is a humanized monoclonal antibody against vascular endothelial growth factor receptor-2, which inhibits the binding of vascular endothelial growth factor- $\mathrm{A},-\mathrm{C}$ and $-\mathrm{D}$ ligands. Furthermore it blocks the ligand stimulated activation of $\mathrm{p} 44 / \mathrm{p} 42$ mitogen activated protein kinases, thus neutralizing the ligand induced proliferation and migration of human endothelial cells. Based on the results of the REGARD (Ramucirumab monotherapy for previously treated advanced gastric or gastro-oesophageal junction adenocarcinoma) and the RAINBOW (Ramucirumab plus paclitaxel versus placebo plus paclitaxel in patients with previously treated advanced gastric or gastrooesophageal junction adenocarcinoma) studies ramucirumab was approved for 2 nd line treatment as monotherapy and in combination with paclitaxel for patients with local relapse and unresectable or metastatic gastric cancer (including gastro-esophegal junction adenocarcinoma). Based on the results, in advanced solid malignancies, ramucirumab may prolong progression free survival and overall survival, although it may increase the risk of all adverse events (fatigue, neutropenia, haemorrhage, nausea, stomatitis). The authors review the clinical studies of ramucirumab.

Keywords: ramucirumab, humanized monoclonal antibody, gastric cancer, solid malignancies

Telekes, A., Deme, D. [Ramucirumab - a new anticancer agent]. Orv. Hetil., 2016, 157(40), 1587-1594.

(Beérkezett: 2016. június 1.; elfogadva: 2016. július 27.)

\section{Rövidítések}

$5 \mathrm{FU}=5$-fluorouracil; $\mathrm{AUC}=$ görbe alatti terület $; \mathrm{C}_{\min }=$ minimális plazmakoncentráció; $\mathrm{CI}=$ konfidenciaintervallum; ECOG = Eastern Cooperative Oncology Group; FGFR = fibroblast növekedési faktor receptor; FOLFIRI = irinothecan, folinsav, 5-fluorouracil; FOLFOX = oxaliplatin, folinsav, 5-flu- orouracil; GEJ = gastrooesophagealis átmenet; $\mathrm{HCC}=$ hepatocellularis carcinoma; $\mathrm{HR}=$ kockázati arány; $\mathrm{mCRC}=$ áttétes vastag- és végbélrák; mCRPC = áttétes kasztrációrezisztens prosztatarák; NSCLC $=$ nem kissejtes tüdőrák; OS = teljes túlélés; PFS = progressziómentes túlélés; $\mathrm{RR}$ = válaszarány; VEGFR = vascularis endothelialis növekedési faktor receptor 


\section{A gyógyszer és hatásmechanizmusa}

A ramucirumab egy humanizált immunoglobulin-G-1 alcsoportba tartozó monoklonális antitest, amely a VEGF-receptor-2-höz (VEGFR-2) kötődve gátolja a receptoraktivációt és ezáltal az intracelluláris jelátviteli utakat. A daganatok érellátása (és ezáltal a tápanyagok biztosítása) a primer daganat és a metasztázisok növekedésének fontos feltétele. Jelenlegi tudásunk szerint ebben a VEGF-rendszer alapvetố szerepet játszik. A VEGFrendszer öt ligandot (VEGF-A, -B, -C, -D, -E) és három receptort - VEGFR-1(flt l), VEGFR-2 (KDR: kinaseinsert domain receptor) és VEGFR-3 (flt 4) - tartalmaz. A receptorok közül a VEGFR-2 játssza a legfontosabb szerepet a daganatfüggő angiogenezisben [1]. A VEGFR-2-/- knock-out egerek a kialakuló szigetszerü vérzésekben, az endothelialis és haematopoeticus sejtek defektusaiban pusztultak el. A VEGFR-2 egy sejtfelszíni, transzmembrán kinázreceptor, amely elsősorban a vascularis endothelsejteken található, de kimutatható a megakaryocytákban és haematopoeticus sejtekben is [2]. A VEGFR-2-receptorhoz az öt ligand közül négy képes kötődni (VEGF-A, -C, -D, -E). A VEGFR-2-ligand-kötődés következményeként a sejten belül több jelátviteli út aktiválódik és ennek következtében fokozódik a tumorangiogenezis [3]. Annak ellenére, hogy a VEGF-A receptorkötő affinitása a VEGFR-2-receptorhoz csak tizede a VEGFR-1-hez mutatott aktivitásnak, mégis a VEGFR-2-t tekintik a tumor-angiogenezis fószereplőjének, mivel a foszforilációja által elindított intracelluláris jelátviteli kaszkád hatékonyabb intermediereket aktivál, mint a másik két receptor [4]. A VEGF-ellenes terápiák az onkológiai gyógyszerfejlesztések élvonalába kerültek [5]. A VEGF-rendszert és az ellene kifejlesztett terápiákat az 1. ábra mutatja. A ramucirumab hatásmechanizmusát a 2. ábrán tüntettük fel.

A ramucirumab szelektíven kötődik a VEGFR-2-receptor extracelluláris kötőhelyéhez. A gyógyszer $\mathrm{IC}_{50^{-}}$ értéke 0,8-1,0 nM [6]. Fontos, hogy a ramucirumab receptoraffinitása nyolcszorosa a természetes ligandoknak. Ramucirumab adását követően a VEGF-ligandok mennyiségének növekedését és a VEGFR-2-receptor csökkenését észlelték, ami megfelel a szelektív receptorgátlás következményének. Mi több, a $8-16 \mathrm{mg} / \mathrm{kg}$ dózistartományban a plazmafelezési idő 200-300 óra, a steady-state koncentráció elérése után [7]. A ramucirumab farmakokinetikája nemlineáris, az emelkedő dózisokkal a clearance csökken [8]. A ramucirumab adagolása testsúlykilogramm szerint történik, intravénásan. A szert fiziológiás $\mathrm{NaCl}$-dal kell hígítani. A ramucirumab hatékony angiogenezis-gátlónak bizonyult gyomordaganatok esetén [9].

A ramucirumab és kemoterápiás kombináció potenciális mellékhatásaként sporadikus angioma alakulhat ki. A VEGFR-2-t kódoló KDR-gén p.T771R-mutációja esetén fokozódik az érképződés, így az angioma kialakulásának nő az esélye a ramucirumabkezelés alatt [10].

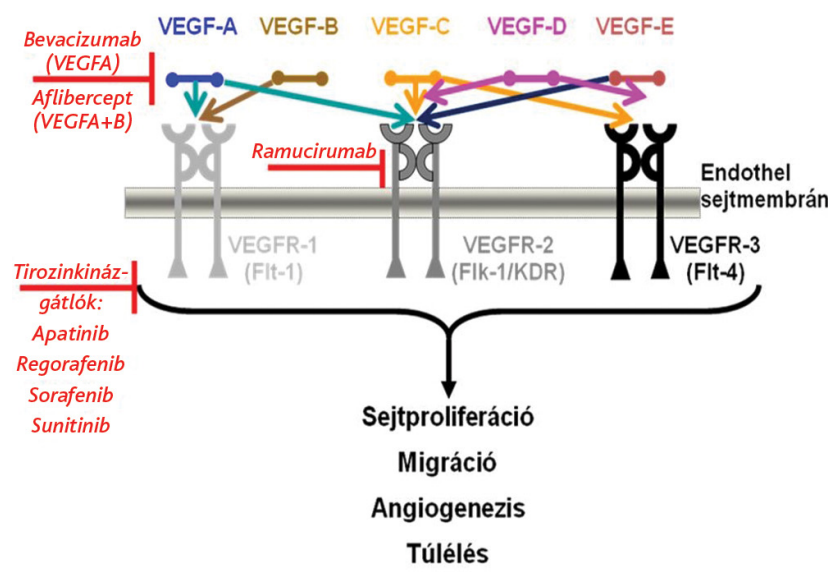

1. ábra A VEGF-rendszer és az ellene kifejlesztett terápiák

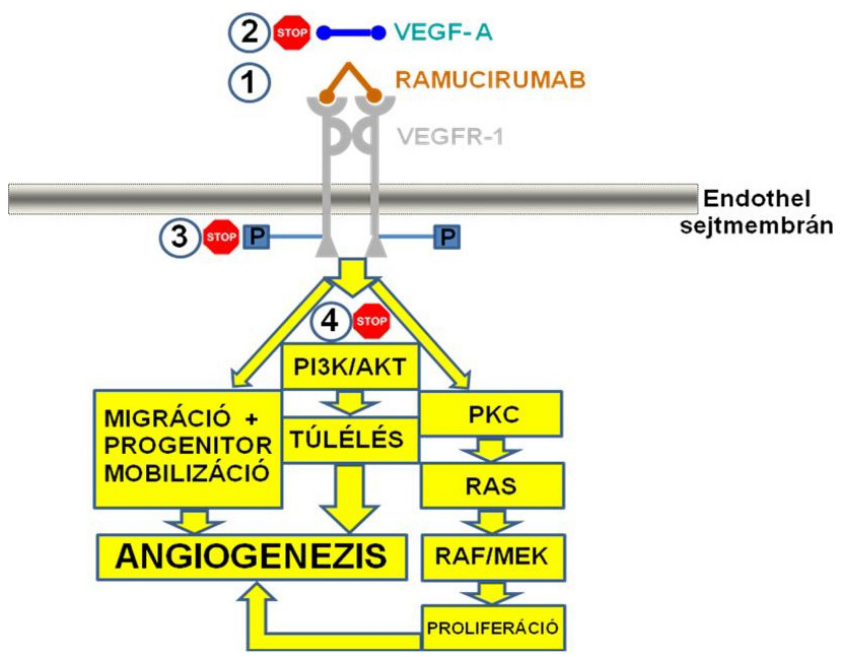

2. ábra

A ramucirumab hatásmechanizmusa: 1. A ramucirumab a VEGFR-2 extracelluláris doménjéhez kötődik. 2. Gátolja a VEGF-A kötődését. 3. Gátolja a VEGFR-2 foszforilációját. 4. Gátolja a downstream szignálútvonalakat

\section{Preklinikai vizsgálatok}

A DC101 (a ramucirumab egerekben alkalmazható verziója) a VEGFR-2-ellenes terápiák in vivo experimentális vizsgálatára lett kifejlesztve. A DC101 gátolta a tumornövekedést egérxenograft-modellben [11]. Mi több, egérmodellben tumorreszekciót követôen a DC101 gátolta a metasztázisképződést [12]. Mivel a VEGFR-2-ellenes DC101 igazolta a terápiás várakozásokat [13-15], így került kifejlesztésre a teljesen humanizált ramucirumab, mivel a humán IgG-1 jóval kevésbé immunogén, mint a nem teljesen humanizált monoklonális antitestek, így a klinikai vizsgálatokban jobban tolerálhatók [16]. A DCl01 $20 \mu \mathrm{g} / \mathrm{ml}$ koncentrációban megfelelő terápiás hatást mutatott. Az állatkísérletek során a koncentrációnadír $\left(C_{\min }\right)$ nem csökkent a $20 \mu \mathrm{g} / \mathrm{ml}$ érték alá, ezért a klinikai vizsgálatok számára is ezt a célkoncentrációt választották [17]. 


\section{Fázis I-II vizsgálatok}

Az első fázis I és dóziskereső vizsgálatot 25 betegen végezték, akik előrehaladott szolid tumorokban szenvedtek, és akik már kimerítették a standard kezelés összes lehetőségét. A dózisokat $2 \mathrm{mg} / \mathrm{kg}$ kezdő dózisról 16 $\mathrm{mg} / \mathrm{kg}$ dózisig emelték 7 lépésben $(2 \mathrm{mg} / \mathrm{kg}, 4 \mathrm{mg} / \mathrm{kg}$, $6 \mathrm{mg} / \mathrm{kg}, 8 \mathrm{mg} / \mathrm{kg}, 10 \mathrm{mg} / \mathrm{kg}, 13 \mathrm{mg} / \mathrm{kg}, 16 \mathrm{mg} / \mathrm{kg}$ ). Egy adott beteg esetén a dózisemelés nem volt megengedett. A maximális tolerálható dózisnak a $13 \mathrm{mg} / \mathrm{kg}$ bizonyult hetente adva. A dózislimitáló toxicitás a grade 3 hypertensio kialakulása volt. A betegek több mint 25\%ában előforduló mellékhatások/tünetek (a ramucirumabtól való függésüket nem vizsgálták) a következők voltak: fáradtság $(51,4 \%)$, fejfájás $(51,4 \%)$, perifériás oedema $(35,1 \%)$, hasmenés $(35,1 \%)$, hányinger $(32,4 \%)$, felső légúti infekció $(32,4 \%)$, hasi fájdalom $(29,7 \%)$, anorexia $(29,7 \%)$, székrekedés $(29,7 \%)$, orrvérzés $(29,7 \%)$, proteinuria $(29,7 \%)$, ízületi fájdalom $(27,0 \%)$, köhögés (27,0\%) és nehézlégzés $(27,0 \%)$.

A farmakokinetikai vizsgálatok azt igazolták, hogy a ramucirumab clearance-e a $8 \mathrm{mg} / \mathrm{kg}$ dózisnál telítődik, ami arra utal, hogy az összes VEGFR-2-receptor gátolva van ennél a dózisnál. A preklinikai adatok alapján előre meghatározott $\mathrm{C}_{\text {min }}$-értéket $(20 \mu \mathrm{g} / \mathrm{ml})$ minden beteg esetén elérték. A standard dózisnak a fentiek alapján a 8 $\mathrm{mg} / \mathrm{kg}$-ot választották, 60 perces infúzióban, kéthetente [18]. A biztonságosság megfelelő volt, grade 3 toxicitást néhány esetben észleltek, köztük a hypertensiót, mélyvénás trombózist, proteinuriát és hányást. Fontos, hogy már a fázis I vizsgálat során észleltek terápiás hatást. A 27 mérhető elváltozás követése során 4 betegnél (11\%) észleltek parciális remissziót, ami 12 hétig tartott, komplett remisszió nem volt. A terápiás válaszok közül kettőt a 4 $\mathrm{mg} / \mathrm{kg}$ dózisnál (melanoma és gyomordaganat), egyet a $13 \mathrm{mg} / \mathrm{kg}$ dózisnál (leiomyosarcoma) és egyet a $16 \mathrm{mg} /$ $\mathrm{kg}$ dózisnál (ováriumcarcinoma) észleltek. A többi 21 betegnél a stabil betegség volt az elért legjobb terápiás válasz. Egy másik fázis I vizsgálatban 14 beteget vizsgáltak. Itt a gyógyszert kéthetente adták $6-10 \mathrm{mg} / \mathrm{kg}$ dózisban. A szükséges minimum plazmakoncentrációt $\left(\mathrm{C}_{\min }\right)$ ebben a vizsgálatban is minden beteg esetén elérték [19]. A ramucirumabbal összesen 7 fázis I vizsgálatot végeztek (NCT00793975, NCT00786383, NCT01005355, NCT01253525, NCT01515306, NCT01567163, NCT01634555), ezekben összesen 174 beteg vett részt. A fázis I vizsgálatokat az 1. táblázat foglalja össze.

1. táblázat |A fázis I vizsgálatok összefoglalása

\begin{tabular}{|c|c|c|c|c|c|c|c|}
\hline & NCT00786383 & NCT00793975 & NCT01005355 & NCT01253525 & NCT01515306 & NCT01567163 & NCT01634555 \\
\hline $\mathrm{N}$ & 25 & 37 & 15 & 6 & A: $24 ; B: 16$ & 22 & 29 \\
\hline Daganat & $\begin{array}{l}\text { Elörehaladott } \\
\text { szolid daganat }\end{array}$ & $\begin{array}{l}\text { Előrehaladott } \\
\text { szolid daganat }\end{array}$ & $\begin{array}{l}\text { Előrehaladott } \\
\text { szolid daganat }\end{array}$ & Adenocarcinoma & $\begin{array}{l}\text { Előrehaladott } \\
\text { szolid daganat }\end{array}$ & $\begin{array}{l}\text { Előrehaladott } \\
\text { szolid daganat }\end{array}$ & $\begin{array}{l}\text { Szolid } \\
\text { tumorok }\end{array}$ \\
\hline Kezdő dózis & $6 \mathrm{mg} / \mathrm{ttkg}$ & $\begin{array}{l}2 \mathrm{mg} / \mathrm{ttkg} \text {, } \\
2 \text { hetente }\end{array}$ & $\begin{array}{l}6-8-10 \mathrm{mg} / \mathrm{ttkg}, \\
2 \text { hetente, } \\
6 \text { hétig, } \\
3 \text { kohorsz- } \\
\text { csoportban } \\
(3-6-6 \text { beteg) }\end{array}$ & $\begin{array}{l}8 \mathrm{mg} / \mathrm{ttkg}, \\
1,15 \text { nap } \\
+ \text { paclitaxel } 80 \\
\mathrm{mg} / \mathrm{m}^{2}, 1,8, \\
15 \text { nap; } \\
28 \text { napos } \\
\text { ciklusokban }\end{array}$ & $\begin{array}{l}\text { A: } 1 \text {. ciklus } \\
\text { paclitaxel } 80 \\
\mathrm{mg} / \mathrm{m}^{2}, \text { utána } \\
\mathrm{R}: 8 \mathrm{mg} / \mathrm{ttkg}, \\
1,15 \mathrm{nap} \\
+ \text { paclitaxel } 80 \\
\mathrm{mg} / \mathrm{m}^{2}, 1,8, \\
15 \text { nap } 28 \\
\text { napos } \\
\text { ciklusban; } B: 1 . \\
\text { ciklus } \mathrm{R} 8 \mathrm{mg} / \\
\text { ttkg, utána, } \\
\text { mint } A \text {-ban }\end{array}$ & $\begin{array}{l}1 \text { ciklus } \\
\text { docetaxel } 75 \\
\mathrm{mg} / \mathrm{m}^{2}, \text { utána } \\
\mathrm{R}: 10 \mathrm{mg} / \mathrm{ttkg} \text {, } \\
\text { docetaxel } 75 \\
\mathrm{mg} / \mathrm{m}^{2} 1 \text { nap, } \\
3 \text { hetes } \\
\text { ciklusokban }\end{array}$ & $\begin{array}{l}8 \mathrm{mg} / \mathrm{ttkg} \\
+ \text { FOLFIRI } \\
\text { (irinothecan } \\
180 \mathrm{mg} / \mathrm{m}^{2}, \\
5-\mathrm{FU} 400 \mathrm{mg} \\
\text { bolus, majd } \\
2044 \mathrm{mg} / \mathrm{m}^{2}, \\
48 \text { órán át, } \\
2 \text { hetes } \\
\text { ciklusokban) }\end{array}$ \\
\hline
\end{tabular}

\begin{tabular}{|c|c|c|c|c|c|c|c|}
\hline Dózisemelés & $\begin{array}{l}6-8-10-15-20 \\
\mathrm{mg} / \mathrm{ttkg}\end{array}$ & $\begin{array}{l}2-4-6-8-10- \\
13-16 \mathrm{mg} / \mathrm{ttkg}\end{array}$ & & & & & \\
\hline $\begin{array}{l}\text { Maximális } \\
\text { tolerálható dózis }\end{array}$ & & $\begin{array}{l}13 \mathrm{mg} / \mathrm{ttkg} \\
\text { hetente }\end{array}$ & & & & & \\
\hline Életkor & $\begin{array}{l}\text { Medián 63,9 } \\
(29,5-79,5) \text { év }\end{array}$ & $\begin{array}{l}\text { Medián } 58 \\
(35-76) \text { év }\end{array}$ & $\begin{array}{l}18-65 \text { év } \\
\mathrm{n}=13 \\
>65 \text { év } \\
\mathrm{n}=2\end{array}$ & $\begin{array}{l}\text { átlagéletkor: } \\
57,6 \text { év }\end{array}$ & $\begin{array}{l}A: 18-65 \text { év, } \\
\mathrm{n}=13 ; \\
>65 \text { év, } \mathrm{n}=10 ; \\
B: 18-65 \text { év, } \\
\mathrm{n}=10 ; \\
>65 \text { év, } \mathrm{n}=6\end{array}$ & $\begin{array}{l}18-65 \text { év, } \\
\mathrm{n}=14 ; \\
>65 \text { év, } \mathrm{n}=8\end{array}$ & $\begin{array}{l}18-65 \text { év, } \\
\mathrm{n}=19 ; \\
>65 \text { év, } \mathrm{n}=10\end{array}$ \\
\hline Megjegyzés & $\begin{array}{l}\text { Az Amerikai } \\
\text { Egyesült } \\
\text { Államokban } \\
\text { végezték }\end{array}$ & $\begin{array}{l}\text { Az Amerikai } \\
\text { Egyesült } \\
\text { Államokban } \\
\text { végezték }\end{array}$ & $\begin{array}{l}\text { Japánban } \\
\text { végezték }\end{array}$ & $\begin{array}{l}\text { Japánban } \\
\text { végezték }\end{array}$ & $\begin{array}{l}\text { Az Amerikai } \\
\text { Egyesült } \\
\text { Államokban } \\
\text { végezték }\end{array}$ & $\begin{array}{l}\text { Az Amerikai } \\
\text { Egyesült } \\
\text { Államokban } \\
\text { végezték }\end{array}$ & $\begin{array}{l}\text { Az Amerikai } \\
\text { Egyesült } \\
\text { Államokban } \\
\text { végezték }\end{array}$ \\
\hline
\end{tabular}

$\mathrm{R}=$ ramucirumab. 
Egy fázis II vizsgálatba 164, előzetesen nem kezelt, előrehaladott nyelőcsődaganatban, gastrooesophagealis átmenet (GEJ-) daganatban és gyomorrákban szenvedő beteget vontak be. Valamennyi beteg módosított FOLFOX-kezelésben részesült, és ramucirumabot $(8 \mathrm{mg} /$ $\mathrm{kg}$ ) vagy placebót kaptak [20]. Az elsődleges végpont a PFS volt, a másodlagos az RR, OS és biztonságosság. Bár a betegségkontroll-ráta a ramucirumabkaron magasabb volt, mint a kontrollkaron $(87 \%$ vs. $67 \%)$, sem a medián PFS (6,44 hónap vs. 6,74 hónap; HR: 0,98; 95\% CI: 0,69-1,37), sem a medián OS (11,7 hónap vs. 11,5 hónap; HR: 1,08; 95\% CI: 0,73-1,58) nem különbözött. További elemzések kimutatták, hogy a PFS a gyomor- és a GEJ-daganatban jelentősen magasabb volt. Mivel a nyelőcsődaganat ismerten nem igazán reagál az angiogenezis-inhibitorokra, ezért az oesophagusdaganatok bevonásával magyarázták a két kar közötti különbség hiányát.

Egy fázis II vizsgálatban 42, előrehaladott állapotú vagy metasztatikus primer májrákos beteg vizsgálati értékeit tanulmányozták. Az eredmény igen ígéretesnek tünt (betegségkontroll-ráta 69\%, medián PFS 4 hónap, OS 12 hónap). A vizsgálatba került betegek többségének májfunkciós értékei megfelelőek voltak. Amikor az értékelést a különböző alcsoportok szerint is elvégezték, azt észlelték, hogy a ramucirumabkezelés hatékonyabb volt a Child-Pugh B csoportban annál, mint amit a ChildPugh A csoportnál észleltek (18 hónap vs. 4,4 hónap) [21].

Egy másik fázis II vizsgálat során a ramucirumab + paclitaxel + carboplatin kombinációs kezelés eredményeit értékelték első vonalban III/IVB stádiumú NSCLC-betegek esetén $(\mathrm{n}=40)$ [22]. A vizsgálat kérdése az volt, hogy a ramucirumab hozzáadásával az első vonalú paclitaxel + carboplatin kombinációhoz el lehet-e érni a bevacizumab korábbi, hasonló vizsgálata során a 6 hónapos kontrollnál észlelt PFS-rátát. Az első napon a betegek először $10 \mathrm{mg} / \mathrm{kg}$ ramucirumabot kaptak iv. >60 perces infúzióban, majd paclitaxelt $\left(200 \mathrm{mg} / \mathrm{m}^{2}\right.$ iv., $>3$ órás infúzióban), végül carboplatint (AUC $6,>30$ perces infúzióban). A paclitaxel előtt a betegek premedikációban részesültek, például 6 és 12 órával az infúzió előtt orális 20 mg dexamethasont kaptak vagy ezzel egyenértékú iv. szteroidot az infúziót közvetlenül megelőzően, antihisztamint $\left(\mathrm{H}_{1}\right.$-antagonista) és antiemetikumot (például cimetidin $300 \mathrm{mg}$ iv.). A ciklusokat - maximum 6 ciklusig - 21 naponta ismételték. A vizsgálat elsődleges végpontja a PFS-ráta volt 6 hónapnál, másodlagos végpontok a PFS, OS, objektív RR volt, ezenfelül tanulmányozták a vizsgált készítmény farmakokinetikáját és biztonságosságát, illetve a hatékonysággal összefüggést mutató biomarkereket kerestek. A betegek 59\%-a ért el 6 hónapos PFS-t (95\% CI: 41,3-72,9\%), ez a bevacizumabos vizsgálatnál (ECOG-E4599 [23]) 55\% volt. A medián PFS, medián OS és objektív RR a ramicurimab- és bevacizumabvizsgálatban a következők voltak: 7,85 (95\% CI: 5,49-9,86) hónap, illetve 6,2 hónap; 16,85 (95\% CI:
14,82-28,58) hónap, illetve 12,3 hónap; 55\% (95\% CI: $38,5-70,7 \%)$ és 35\% voltak. Érdekes módon az FGFR2 -receptor gén single-nucleotide polimorfizmusa (rs2981582) szignifikáns korrelációt mutatott a teljes túléléssel. Mivel az eredmények a historikus kontrollal összevethetők voltak, de a bevacizumabvizsgálattal ellentétben a ramucirumabkaron nem volt kezeléssel összefüggő halálozás, ezért a készítmény további fejlesztését javasolták a szerzők NSCLC első vonalú kezelésére.

Egy másik fázis II vizsgálatba előrehaladott, nem laphám NSCLC-daganatban szenvedő betegeket $(\mathrm{n}=140)$ vontak be [24]. A vizsgálat során a betegeket $1: 1$ arányban randomizálták. Az $A$ karon a betegek háromhetente maximum 6 ciklus cisplatin- vagy carboplatin + pemetrexed kezelésben részesültek, majd fenntartó kezelésként pemetrexedet kaptak. A $B$ karon ugyanazt a kemoterápiát alkalmazták $10 \mathrm{mg} / \mathrm{kg}$ ramucirumabbal együtt, majd fenntartó kezelésként a betegek ramucirumabot + pemetrexedet kaptak. A vizsgálat elsődleges végpontja a PFS volt, ami az $A$ és $B$ karon 5,6 hónap, illetve 7,2 hónap volt (HR: 0,$75 ; \mathrm{p}=0,132)$. A betegségkontroll-ráta már szignifikáns különbséget eredményezett: $A$ kar = $70 \%, B$ kar $=86 \%(\mathrm{p}=0,031)$. A ramucirumab hozzáadása a kemoterápiához nem eredményezett nem várt mellékhatásokat. A leggyakoribb grade 3 mellékhatások a neutropenia, hányinger, hypertonia, hátfájás és fáradékonyság voltak.

Docetaxellel előkezelt mCRPC-ben végzett fázis II vizsgálatban $(\mathrm{n}=132)$ hasonlították össze a ramucirumab $(\mathrm{R})+$ mitoxantron $(\mathrm{M})+$ prednisolon $(\mathrm{P})$ hatását a cixutumumab $(\mathrm{C})+\mathrm{MP}$-vel. A 21 napos ciklusban a ramucirumabot $6 \mathrm{mg} / \mathrm{kg}$ dózisban hetente adták. Medián cPFS R + MP-re 6,7 hónap (95\%-os CI: 4,5-8,3) és C + MP-re 4,1 hónap (95\%-os CI 2,2-5,6), és a medián OS 13 és 10,8 hónap volt a fenti sorrendben. A fáradtság volt a leggyakoribb nemkívánatos esemény. A nem hematológiai grade 3-4 nemkívánatos események incidenciája < $10 \%$ volt mindkét karon. Kardiális diszfunkció 7,6\%-ban jelentkezett a ramucirumabkaron [25].

A fázis II vizsgálatokat a 2. táblázat foglalja össze.

\section{Fázis III vizsgálatok}

Ez ideig gyomor- és GEJ-daganatok bevonásával két fázis III vizsgálatot végeztek, nevezetesen a REGARD (NCT00917384) és RAINBOW (NCT01170663) vizsgálatot. Az első vizsgálatban 355, a másodikban 655 beteg vett részt. A REGARD vizsgálatban a két kar ramucirumab $(\mathrm{R})+$ BSC (best supportive care) és placebo $(\mathrm{P})+$ BSC volt, $2: 1$ arányú randomizációval $(\mathrm{R}+\mathrm{BSC}$ : 238 beteg, P + BSC: 117 beteg) [26]. A vizsgálatba azok a betegek léphettek be, akiknek az ECOG PS 0-1 volt, és 4 hónapon belül progrediáltak a metasztatikus első vonalú kezelést követően, vagy 6 hónapon belül az adjuváns 5 -FU + platina kezelés után. A betegek kéthetente kapták a ramucirumabot $8 \mathrm{mg} / \mathrm{kg}$ dózisban. A vizsgálatban a betegek csak az egyik karon vehettek részt, a cross- 
2. táblázat |A fázis II. vizsgálatok összefoglalása

\begin{tabular}{|c|c|c|c|c|c|}
\hline $\mathrm{N}$ & 164 & 42 & 40 & 140 & 132 \\
\hline Daganat & $\begin{array}{l}\text { Előrehaladott } \\
\text { nyelőcső, GEJ, } \\
\text { gyomor }\end{array}$ & $\mathrm{mHCC}$ & NSCLC st. III/IVb & $\begin{array}{l}\text { Előrehaladott, nem } \\
\text { laphám NSCLC }\end{array}$ & mCRPC docetaxel után \\
\hline $\mathrm{Tx}$ & $\mathrm{mFOLFOX}+\mathrm{R} / \mathrm{P}$ & & $\mathrm{TAX}+\mathrm{CBP}+\mathrm{R}$ & $\begin{array}{l}\text { Platina }+ \text { PEM }+/-\mathrm{R} \\
\text { és fenntartó } \\
\mathrm{PEM}+/-\mathrm{R}\end{array}$ & $\begin{array}{l}\text { Mitoxanthron + prednisolon }+ \\
\text { R/C }\end{array}$ \\
\hline R-dózis & $8 \mathrm{mg} / \mathrm{ttkg}$ & & $10 \mathrm{mg} / \mathrm{ttkg}$ & $10 \mathrm{mg} / \mathrm{ttkg}$ & $\begin{array}{l}6 \mathrm{mg} / \mathrm{ttkg} \text { hetente } 21 \text { napos } \\
\text { ciklusban }\end{array}$ \\
\hline $\begin{array}{l}\text { Betegségkontroll- } \\
\text { ráta }\end{array}$ & $\begin{array}{l}\text { R } 87 \% \\
\text { P } 67 \%\end{array}$ & R 69\% & & $\begin{array}{l}+\mathrm{R} 86 \% \\
-\mathrm{R} 70 \%\end{array}$ & \\
\hline PFS & $\begin{array}{l}\text { R 6,44 hó } \\
\text { P 6,74 hó }\end{array}$ & 4 hó & 7,85 hó & $\begin{array}{l}\text { +R 7,2 hó } \\
-\mathrm{R} 5,6 \text { hó }\end{array}$ & $\begin{array}{l}\text { R 6,7 hó } \\
\text { C } 4,1 \text { hó }\end{array}$ \\
\hline OS & $\begin{array}{l}\text { R 11,7 hó } \\
\text { P 11,5 hó }\end{array}$ & 12 hó & 16,85 hó & & $\begin{array}{l}\text { R } 13 \text { hó } \\
\text { C 10,8 hó }\end{array}$ \\
\hline PFS-ráta & & & $\begin{array}{l}59 \% \text { ( } 6 \text { hónapra } \\
\text { vonatkoztatva) }\end{array}$ & & \\
\hline $\begin{array}{l}\text { Objektív } \\
\text { válaszarány }\end{array}$ & & & $55 \%$ & & \\
\hline
\end{tabular}

$\mathrm{C}=$ cixutumumab; $\mathrm{P}=$ placebo $; \mathrm{PEM}=$ pemetrexed $\mathrm{R}$ = ramucirumab; $\mathrm{TAX}=$ paclitaxel $; \mathrm{T}$ = terápia .

3. táblázat |A fázis III vizsgálatok összefoglalása

\begin{tabular}{|c|c|c|c|c|c|}
\hline & REGARD & RAINBOW & REACH & REVEL & RAISE \\
\hline $\mathrm{N}$ & 355 & 665 & 565 & 1253 & \\
\hline Daganat & $\begin{array}{l}\text { Előrehaladott vagy } \\
\text { metasztatikus } \\
\text { gyomor/GEJ daganat }\end{array}$ & $\begin{array}{l}\text { Metasztatikus vagy } \\
\text { rekurrens gyomorrák }\end{array}$ & Előrehaladott HCC & mNSCLC & mCRC \\
\hline $\mathrm{Tx}$ & 2nd line $\mathrm{BSC}+\mathrm{R} / \mathrm{P}$ & $\begin{array}{l}\text { 2nd line } \\
\mathrm{TAX}+\mathrm{R} / \mathrm{P}\end{array}$ & $\begin{array}{l}\text { 2nd line } \\
\mathrm{R} / \mathrm{P}\end{array}$ & $\begin{array}{l}\text { 2nd line } \\
\text { docetaxel }+\mathrm{R} / \mathrm{P}\end{array}$ & $\begin{array}{l}\text { 2nd line } \\
\text { FOLFIRI }+\mathrm{R} / \mathrm{P}\end{array}$ \\
\hline R-dózis & $8 \mathrm{mg} / \mathrm{ttkg} 2$ hetente & $8 \mathrm{mg} / \mathrm{ttkg} 2$ hetente & & $10 \mathrm{mg} / \mathrm{ttkg} 3$ hetente & \\
\hline Betegségkontroll-ráta & $\begin{array}{l}\text { R } 49 \% \\
\text { P 23\% } \\
\end{array}$ & $\begin{array}{l}\text { R } 80 \% \\
\text { P 64\% } \\
\end{array}$ & & & \\
\hline PFS & $\begin{array}{l}\text { R 2,1 hó } \\
\text { P 1,3 hó }\end{array}$ & $\begin{array}{l}\text { R 4,4 hó } \\
\text { P 2,8 hó }\end{array}$ & & $\begin{array}{l}\text { R } 4,5 \text { hó } \\
\text { P } 3 \text { hó }\end{array}$ & $\begin{array}{l}\text { R } 7,7 \text { hó } \\
\text { P 4,5 hó }\end{array}$ \\
\hline OS & $\begin{array}{l}\text { R 5,2 hó } \\
\text { P 3,8 hó }\end{array}$ & $\begin{array}{l}\text { R 9,6 hó } \\
\text { P 7,3 hó }\end{array}$ & $\begin{array}{l}\text { R 9,2 hó } \\
\text { P 7,6 hó }\end{array}$ & $\begin{array}{l}\text { R 10,5 hó } \\
\text { P 9,1 hó }\end{array}$ & $\begin{array}{l}\text { R 13,3 hó } \\
\text { P 11,7 hó }\end{array}$ \\
\hline Objektív válaszarány & & $\begin{array}{l}\text { R 28\% } \\
\text { P } 16 \%\end{array}$ & & $\begin{array}{l}\text { R 23\% } \\
\text { P } 14 \%\end{array}$ & \\
\hline
\end{tabular}

$\mathrm{P}=$ placebo $\mathrm{R}=$ ramucirumab; $\mathrm{TAX}=$ paclitaxel.

over terápiára (azaz a placebokarról a ramucirumabkarra való kerülésre progresszió esetén) nem volt lehetőség. A vizsgálat elsődleges végpontja az OS volt. A medián OS az R + BSC karon 5,2 hónapnak, a P + BSC karon 3,8 hónapnak bizonyult $(\mathrm{p}=0,047)$. A medián PFS időtartama ugyancsak szignifikáns eltérést mutatott $(2,1$ hónap vs. 1,3 hónap; HR 0,48; $\mathrm{p}<0,0001)$. A terápia medián időtartama a két karon ugyancsak különböző volt ( $\mathrm{R}+\mathrm{BSC} 8$ hét, $\mathrm{P}+\mathrm{BSC} 6$ hét). Az RR nem mutatott szignifikáns eltérést $(\mathrm{R}+\mathrm{BSC} 3,4 \%$ vs. $\mathrm{P}+\mathrm{BSC} 2,6 \%)$, a betegségkontroll-ráta azonban igen ( $\mathrm{R}+\mathrm{BSC} 49 \%$, $\mathrm{P}+$ BSC 23\%; $\mathrm{p}<0,0001)$. Az alcsoport-analízis valamennyi vizsgált stratumban (például testsúlycsökkenés szerint, a primer tumor lokalizációja szerint) kimutatta a ramucirumabkezelés előnyét a placebóval szemben. Érdekes módon úgy tûnt, hogy a férfi betegek többet profitáltak a ramucirumabkezelésből, mint a nőbetegek. A HR a teljes túlélés szempontjából a férfiak és nók esetén a következők voltak: 0,67 (95\% CI: 0,49-0,91), illetve 1,43 (95\% CI: 0,85-2,40). A ramucirumab jól tolerálhatónak bizonyult, a legfontosabb mellékhatás a vérnyomás emelkedése (8\%) volt (ez a BSC-karon 3\%nak bizonyult), grade 4 hypertonia nem volt. Az életminőség-vizsgálatok azt igazolták, hogy stabil állapot vagy javulás hathetes kezelést követően a ramucirumabkaron $34 \%$, a placebokaron $13 \%$ volt. A vizsgálatban 182 beteg 
volt 65 évesnél idősebb. A terápia hatékonysága a 65 évesnél fiatalabbak és idősebbek között nem különbözött (a túlélés szempontjából a HR: >65 év: 0,72 [95\% CI: 0,4-1,1], illetve <65 év: 0,84 [95\% CI: 0,61-1,17], $\mathrm{p}=0,56)$. A PFS szintén nem különbözött az életkor függvényében. Annak ellenére, hogy az OS-eltérés a két kar között mindössze 1,4 hónap volt, a RAINBOW vizsgálat mégis áttörést jelentett, mivel ez az első vizsgálat, ami egy angiogenezis-gátló terápiás aktivitását kimutatta a teljes túlélés vonatkozásában GEJ-rák és előrehaladott gyomorrák esetén, mi több, ez volt az első vizsgálat, ami ebben az indikációban kimutatta egy célzott terápiás szer monoterápiás aktivitását.

A RAINBOW kettős vak, placebokontrollált vizsgálatban a randomizáció $1: 1$ arányban történt a két kar között ramucirumab + paclitaxel $(\mathrm{R}+\mathrm{P})$, illetve placebo + paclitaxel $(P+P)[27]$. Az első csoportba 330, a másodikba 335 beteget randomizáltak. A betegek az első vonalú 5 -FU + platina kezelés kudarca után kerülhettek a vizsgálatba. A betegek a paclitaxelt $\left(80 \mathrm{mg} / \mathrm{m}^{2}\right)$ az 1 ., a 8 . és a 15. napon kapták, a ramucirumab $(8 \mathrm{mg} / \mathrm{kg})$ az elsó napon került beadásra, majd azt követően kéthetente. A ciklusok 28 naposak voltak. A kezelést progresszióig, elfogadhatatlan toxicitásig vagy a beleegyezés visszavonásáig folytatták. A cross-over itt sem volt engedélyezett. A kezelések medián időtartama az $\mathrm{R}+\mathrm{P}$ és $\mathrm{P}+\mathrm{P}$ karokon 18 , illetve 12 hét volt. A medián $\mathrm{OS}$ az $\mathrm{R}+\mathrm{P}$, illetve $\mathrm{P}+\mathrm{P}$ karon 9,6 , illetve 7,3 hónap volt $(\mathrm{p}=0,0169 ; \mathrm{HR}$ $=0,8)$, a medián PFS pedig 4,4, illetve 2,8 hónapnak bizonyult $(\mathrm{p}<0,0001 ; \mathrm{HR}=0,6)$. Ebben a vizsgálatban az objektív terápiás válaszarány (komplett remiszszió + parciális remisszió) is szignifikáns különbséget mutatott $(\mathrm{R}+\mathrm{P}: 28 \%, \mathrm{P}+\mathrm{P}: 16 \% ; \mathrm{p}=0,0001)$, a betegségkontroll-ráta $80 \%$, illetve $64 \%$ volt $(\mathrm{p}<0,001)$. A legfontosabb mellékhatások a neutropenia, leukopenia, anaemia, hypertonia és fáradékonyság voltak. A grade 3-4 mellékhatások mintegy 20\%-kal megemelkedtek a ramucirumab + paclitaxel kombinációban ( $82 \%$ vs. 63\%). A legfontosabb grade 3-4 mellékhatások az $\mathrm{R}+\mathrm{P}$, illetve $\mathrm{P}+\mathrm{P}$ karokon a következők voltak: neutropenia $40,7 \%$ vs. $18,8 \%$, leukopenia $17,4 \%$ vs. $6,7 \%$, hypertonia $14,1 \%$ vs. $2,4 \%$. A mellékhatások fokozódása azonban nem eredményezte a kezelések nagyobb arányú megszakítását a $\mathrm{R}+\mathrm{P}$ karon, illetve a kezeléssel összefüggésbe hozható halálozás sem különbözött (4,0\% vs. 4,6\%). A COX regressziós analízis hét független prognosztikai faktort állapított meg a túlélés szempontjából: ázsiai rassz, ECOG PS 0 , testsúlycsökkenés $<10 \%$ az elmúlt három hónapban, kevés számú metasztázis, ascites hiánya, jól differenciált tumorhisztológia, előzetes gastrectomia [28]. A mellékhatások ellenére az $\mathrm{R}+\mathrm{P}$ kezelés jól tolerálhatónak bizonyult. Az R + P kezelés megfelelő hatékonyságot mutatott ahhoz, hogy másodvonalú terápiás opcióként számításba kerüljön. A ramucirumab az első angiogenezis-gátló, amit az FDA (Food and Drug Administration) 2014 áprilisában befogadott az előrehaladott gyomor- és GEJ-tumorok kezelésére 5-FU + plati- na kezelés progressziója után monoterápiában [29], illetve 2014. novemberben paclitaxellel kombinációban, másodvonalban.

A fázis II eredménye alapján randomizált, placebokontrollos, kettős vak, multicentrikus fázis III vizsgálat indult primer, előrehaladott hepatocellularis carcinomában REACH néven (NCT01140347), másodvonalban [30]. A vizsgálatban 565 beteg vett részt (27 ország 154 centrumában), akik az első vonalú sorafenibkezelés alatt vagy után progrediáltak vagy azt nem tolerálták. A randomizáció $1: 1$ arányban történt (283 beteg kapott ramucirumabot $[\mathrm{R}], 282$ placebót $[\mathrm{P}])$. A medián túlélés az R csoportban 9,2 (95\% CI: 8,0-10,6) hónap, míg a P csoportban 7,6 (95\% CI: 6,0-9,3) hónap volt (HR: 0,87; 95\% CI: 0,72-1,05; p =0,14). Új mellékhatást nem észleltek. A fázis III vizsgálat nem igazolta a fázis II alapján kialakult várakozásokat.

Egy másik fázis III vizsgálatban (REVEL) nem kissejtes metasztatikus tüdőrákban összehasonlították a ramucirumab $(\mathrm{R})+$ docetaxel $(\mathrm{D})$ kezelést $(\mathrm{n}=628)$ a placebo $(\mathrm{P})$ + docetaxel kezeléssel $(\mathrm{n}=625)$, első vonalú platinaalapú terápiát követő progresszió után [31]. A betegek átlagéletkora 62 év volt. A betegek a docetaxelt $\left(75 \mathrm{mg} / \mathrm{m}^{2}\right) 3$ hetente kapták. Érdekes módon az R-t ugyancsak háromhetente adták $(10 \mathrm{mg} / \mathrm{kg})$. Az elsődleges terápiás végpont az OS volt, a másodlagosak a PFS, objektív RR és szupportáció voltak. Az $\mathrm{R}+\mathrm{D}$ csoport statisztikailag szignifikáns előnyt mutatott a $\mathrm{P}+\mathrm{D}$ csoporttal szemben mind a medián OS (10,5 [95\% CI: 9,511,2] hónap vs. 9,1 [95\% CI: 8,4-10,0] hónap; HR: 0,86 [95\% CI: 0,75-0,98]; p = 0,024), mind a medián PFS (4,5 [95\% CI: 4,2-5,4] hónap vs. 3,0 [95\% CI: 2,83,9] hónap; HR: 0,76 [95\% CI: 0,68-0,86]; p<0,001) vonatkozásában. Az objektív RR-értékek között ugyancsak szignifikáns különbség mutatkozott, R + D 23\% (95\% CI: 20-26), P + D 14\% (95\% CI: 11-17), p<0,001. A REVEL vizsgálat alapján a ramucirumabot az FDA jóváhagyta 2014 decemberében a IV. stádiumú NSCLCbetegek másodvonalú kezelésére [32]. Azoknak a betegeknek, akiknek a daganata EGFR- vagy ALK-mutáns, a ramucirumab előtt ezekre célzott kezelést kell kapniuk.

Fázis III vizsgálat történt metasztatikus vastag- és végbélrákban szenvedő betegeknél is (RAISE trial) [33]. A betegek ramucirumab- vagy placebokezelésben részesültek másodvonalú FOLFIRI-kezeléssel együtt azt követően, hogy progrediáltak az első vonalú kezelés (bevacizumab, oxaliplatin és 5-FU) alatt vagy után. A ramucirumab + FOLFIRI szignifikáns módon hosszabb OS-t eredményezett, mint a placebo + FOLFIRI $(13,3$ vs. 11,7 hónap; HR: 0,84; 95\% CI: 0,73-0,98; $\mathrm{p}=$ 0,0219). A PFS ugyancsak szignifikáns eltérést mutatott (7,7 vs. 4,5 hónap; HR: 0,79; 95\% CI: 0,70-0,90; $\mathrm{p}<0,0005)$.

A fázis III vizsgálatokat a 3. táblázat foglalja össze. 


\section{Jelenleg folyamatban lévő klinikai vizsgálatok}

A gyomor- és nyelőcsődaganatot egyrészt magasabb dózistartományban monoterápiában, másrészt paclitaxellel kombinálva, harmadrészt nab-paclitaxellel együtt vizsgálják. Gyermekeknél refrakter szolid daganatokban monoterápiában, felnőtteknél előkezelt epeúti carcinomában, HCC-ben emelkedett AFP-érték esetén vizsgálják. Gyomor- és GEJ-adenocarcinoma esetén, NSCLC-ben, tranzicionális sejtes urothelialis carcinomában pembrolizumabbal kombinálva vizsgálják. Áttétes GEJ-adenocarcinoma esetén első vonalban ramucirumab + capecitabin + cisplatin kombinációval folyik fázis III vizsgálat (RAINFALL). Előrehaladott daganatokban ramucirumab és LY2875358 kombinációval, mNSCLC-ben erlotinibbel, HCC-ben FOLFOX-4-gyel, urothelialis carcinomában platina utáni progresszióban docetaxellel, mCRC-ben bevacizumab utáni progresszióban cetuximab + irinothecan adásával együtt vizsgálják.

\section{Következtetések}

A gyomorrákban a ramucirumab befogadásáig nem volt standard másodvonalú kezelés, mivel a bevacizumab nem növelte a teljes túlélést. A REGARD és RAINBOW vizsgálatok egymást megerősítő eredményei alapján a ramucirumab-monoterápia és a paclitaxel + ramucirumab kezelés ezt a kérdést jelenleg megoldotta. A tüdődaganatokban mutatott eredmény bár pozitív, a klinikai relevancia azonban megkérdőjelezhető a közölt irányelvek alapján [34]. E szerint NSCLC esetén klinikailag relevánsnak tekinthető a túlélés szempontjából 2,5-4 hónap, a PFS szempontjából 3-4 hónap. A REVEL vizsgálatban a ramucirumab adása 1,4 hónapos OS-előnyt és 1,5 hónapos PFS-előnyt jelentett. Mivel azonban a ramucirumab pozitív hatása az NSCLC valamennyi szövettani típusában kimutatható volt (például a laphámtumorokon is), további tüdőtumoros vizsgálatok javasoltak.

A RAISE vizsgálat alapján vastag- és végbélrákban az OS-előny 1,6 hónap, a PFS-előny 3,2 hónap volt, ebből az OS-érték nem éri el az előző hivatkozásban megállapított klinikailag releváns értéket, míg a PFS igen. Bár mCRC-ben másodvonalú kezelésként ramucirumab és FOLFIRI kombináció jól tolerálható [35], azonban metasztatikus colorectalis carcinoma másodvonalú kezelésében a ramucirumab költséghatékonysága rosszabb, mint a bevacizumab vagy az aflibercept használata során (az OS-nyereség egyenként 1,4 hónap), ezért mCRCben alkalmazása nem gazdaságos. A bevacizumabot tartalmazó kombinációs sémával összehasonlítva a ramucirumabbal történő kezelés több mint kétszer költségesebb. Egy körülbelül $70 \mathrm{~kg}$ súlyú páciens egyhavi ramucirumab (kéthetente $8 \mathrm{mg} / \mathrm{kg}$ dózisban) kezelésének költsége körülbelül 2,2 millió forint [36].
Metasztatikus emlőrákban az eredmények negatívak voltak [37], csakúgy, mint metasztatikus veserákban (objektív RR 5,1\%) [38], ismét bizonyítva, hogy ugyanazon tumorellenes gyógyszerre a különféle daganatok eltérő mértékben reagálnak.

A fentiek alapján a ramucirumab a gyomor- és GEJdaganatok esetén a magyar betegek számára is elérhető kellene, hogy legyen. A tüdő laphámrákjaiban, mCRPCben és más daganatokban a további vizsgálatok fogják meghatározni a ramucirumab helyét és szerepét.

Anyagi támogatás: A közlemény megírása anyagi támogatásban nem részesült.

Szerzői munkamegosztás: T. A.: Irodalmi áttekintés, a dolgozat szövegének megírása, a táblázatok és ábrák kiegészítése. D. D.: A dolgozat szövegének kiegészítése, a táblázatok és az ábrák szerkesztése. A cikk végleges változatát a szerzők elolvasták és jóváhagyták.

Érdekeltségek: A szerzőknek nincsenek érdekeltségeik.

\section{Irodalom}

[1] Kerbel, R. S.: Tumor angiogenesis. N. Engl. J. Med., 2008, 358(19), 2039-2049.

[2] Holmes, K., Roberts, O. L., Thomas, A. M., et al.: Vascular endothelial growth factor receptor-2: structure, function, intracellular signalling and therapeutic inhibition. Cell. Signal., 2007, 19(10), 2003-2012.

[3] Hicklin, D. J., Ellis, L. M.: Role of the vascular endothelial growth factor pathway in tumor growth and angiogenesis. J. Clin. Oncol., 2005, 23(5), 1011-1027.

[4] Aprile, G., Bonotto, M., Ongaro, E., et al.: Critical appraisal of ramucirumab (IMC-1121B) for cancer treatment: from benchside to clinical use. Drugs, 2013, 73(18), 2003-2015.

[5] Smith, N. R., Wedge, S. R., Pommier, A., et al.: Mechanisms that influence tumour response to VEGF-pathway inhibitors. Biochem. Soc. Trans., 2014, 42(6), 1601-1607.

[6] Lu, D., Jimenez, X., Zhang, H., et al.: Selection of high affinity human neutralizing antibodies to VEGFR2 from a large antibody phage display library for antiangiogenesis therapy. Int. J. Cancer, 2002, 97(3), 393-399.

[7] Miao, H. Q., Hu, K., Jimenez, X., et al.: Potent neutralization of VEGF biological activities with a fully human antibody Fab fragment directed against VEGF receptor 2. Biochem. Biophys. Res. Commun., 2006, 345(1), 438-445

[8] Spratlin, J. L., Mulder, K. E., Mackey, J. R.: Ramucirumab (IMC1121B): a novel attack on angiogenesis. Future Oncol., 2010, 6(7), 1085-1094.

[9] Javle, M., Smyth, E. C., Chau, I., et al.: Ramucirumab: successfully targeting angiogenesis in gastric cancer. Clin. Cancer Res., 2014, 20(23), 5875-5881.

[10] Lim, Y. H., Odell, I. D., Ko, C. J., et al.: Somatic p.T77IR KDR (VEGFR2) mutation arising in a sporadic angioma during ramucirumab therapy. JAMA Dermatol., 2015, 151(11), 1240-1243.

[11] Prewett, M., Huber, J., Li, $\Upsilon$., et al.: Antivascular endothelial growth factor receptor (fetal liver kinase 1) monoclonal antibody inhibits tumor angiogenesis and growth of several mouse and human tumors. Cancer Res., 1999, 59(20), 5209-5218.

[12] Franklin, M. C., Navarro, E. C., Wang, Ү., et al.: The structural basis for the function of two anti-VEGF receptor 2 antibodies. Structure, 2011, 19(8), 1097-1107. 
[13] Fong, G. H., Rossant, J., Gertsenstein, M., et al.: Role of the Flt-1 receptor tyrosine kinase in regulating the assembly of vascular endothelium. Nature, 1995, 376(6535), 66-70.

[14] Witte, L., Hicklin, D. J., Zhu, Z., et al.: Monoclonal antibodies targeting the VEGF receptor-2 (Flkl/KDR) as an anti-angiogenic therapeutic strategy. Cancer Metastasis Rev., 1998, 17(2), 155-161.

[15] Bruns, C. J., Liu, W., Davis, D. W., et al.: Vascular endothelial growth factor is an in vivo survival factor for tumor endothelium in a murine model of colorectal carcinoma liver metastases. Cancer, 2000, 89(3), 488-499.

[16] Clarke, J. M., Hurwitz, H. I.: Targeted inhibition of VEGF receptor 2: an update on ramucirumab. Expert Opin. Biol. Ther., 2013, 13(8), 1187-1196.

[17] Wadbwa, R., Taketa, T., Sudo, K., et al.: Ramucirumab: a novel antiangiogenic agent. Future Oncol., 2013, 9(6), 789-795.

[18] Spratlin, J. L., Cohen, R. B., Eadens, M., et al.: Phase I pharmacologic and biologic study of ramucirumab (IMC-1121B), a fully human immunoglobulin Gl monoclonal antibody targeting the vascular endothelial growth factor receptor-2. J. Clin. Oncol., $2010,28(5), 780-787$.

[19] Chiorean, E., Sweeney, C., Hurwitz, H., et al.: Phase I dose-escalation study of the anti-VEGFR-2 recombinant human IgGl MAb IMC-1121B administered every other week ( $22 w)$ or every 3 weeks $(\mathrm{q} 3 \mathrm{w})$ in patients (pts) with advanced cancers. Mol. Cancer Therapeut., 2007, 6(11 Suppl.), B15.

[20] Yoon, H. H., Bendell, J. C., Braiteh, F. S., et al.: Ramucirumab (RAM) plus FOLFOX as front-line therapy $(\mathrm{Rx})$ for advanced gastric or esophageal adenocarcinoma (GE-AC): randomized, double-blind, multicenter phase 2 trial. 2014 ASCO Annual Meeting. J. Clin. Oncol., 2014, 32(Suppl. 5), Abstract 4004.

[21] Zhu, A. X., Finn, R. S., Mulcahy, M., et al.: A phase II and biomarker study of ramucirumab, a human monoclonal antibody targeting the VEGF receptor-2, as first-line monotherapy in patients with advanced hepatocellular cancer. Clin. Cancer Res., $2013,19(23), 6614-6623$

[22] Camidge, D. R., Berge, E. M., Doebele, R. C., et al.: A phase II, open-label study of ramucirumab in combination with paclitaxel and carboplatin as first-line therapy in patients with stage IIIB/ IV non-small-cell lung cancer. J. Thorac. Oncol., 2014, 9(10), 1532-1539.

[23] Sandler, A., Gray, R., Perry, M. C., et al.: Paclitaxel-carboplatin alone or with bevacizumab for non-small-cell lung cancer. N. Engl. J. Med., 2006, 355(24), 2542-2550.

[24] Doebele, R. C., Spigel, D., Tehfe, M., et al.: A phase 2 randomized open-label study of ramucirumab (IMC 1121B; RAM) in combination with first-line platinum-based chemotherapy in patients (pts) with recurrent or advanced non-small cell lung cancer (NSCLC): final results from non-squamous (NSQ) pts. J. Thorac. Oncol., 2013, 8, S290.

[25] Hussain, M., Rathkopf, D., Liu, G., et al.: A randomised noncomparative phase II trial of cixutumumab (IMC-A12) or ramucirumab (IMC-1121B) plus mitoxantrone and prednisone in men with metastatic docetaxel-pretreated castration-resistant prostate cancer. Eur. J. Cancer, 2015, 51(13),1714-1724.

[26] Fuchs, C. S., Tomasek, J., Yong, C. J., et al.: Ramucirumab monotherapy for previously treated advanced gastric or gastro-oesophageal junction adenocarcinoma (REGARD): an international, randomised, multicentre, placebo-controlled, phase 3 trial. Lancet, 2014, 383(9911), 31-39.

[27] Wilke, H., Muro, K., Van Cutsem, E., et al.: Ramucirumab plus paclitaxel versus placebo plus paclitaxel in patients with previ- ously treated advanced gastric or gastro-oesophageal junction adenocarcinoma (RAINBOW): a double-blind, randomised phase 3 trial. Lancet Oncol., 2014, 15(11), 1224-1235.

[28] Wilke, H., Van Cutsem, E., Oh, S. C., et al.: RAINBOW: A global, phase 3 , randomized, double-blind study of ramucirumab plus paclitaxel versus placebo plus paclitaxel in the treatment of metastatic gastric adenocarcinoma following disease progression on first-line platinum- and fluoropyrimidine-containing combination therapy: results of a multiple Cox regression analysis adjusting for prognostic factors. 2014 ASCO Annual Meeting. J. Clin. Oncol., 2014, 32(Suppl. 5), Abstract 4076.

[29] Poole, R. M., Vaidya, A.: Ramucirumab: first global approval. Drugs, 2014, 74(9), 1047-1058.

[30] Zhu, A. X., Park, J. O., Ryoo, B. Ү., et al.: Ramucirumab versus placebo as second-line treatment in patients with advanced hepatocellular carcinoma following first-line therapy with sorafenib $(\mathrm{REACH})$ : a randomised, double-blind, multicentre, phase 3 trial. Lancet Oncol., 2015, 16(7), 859-870.

[31] Garon, E. B., Ciuleanu, T. E., Arrieta, O., et al.: Ramucirumab plus docetaxel versus placebo plus docetaxel for second-line treatment of stage IV non-small-cell lung cancer after disease progression on platinum-based therapy (REVEL): a multicentre, double-blind, randomised phase 3 trial. Lancet, 2014, 384(9944), 665-673.

[32] Larkins, E., Scepura, B., Blumenthal, G. M., et al.: U.S. Food and Drug Administration approval summary: Ramucirumab for the treatment of metastatic non-small cell lung cancer following disease progression on or after platinum-based chemotherapy. Oncologist, 2015, 20(11), 1320-1325.

[33] Tabernero, J., Yoshino, T., Cohn, A. L., et al.: Ramucirumab versus placebo in combination with second-line FOLFIRI in patients with metastatic colorectal carcinoma that progressed during or after first-line therapy with bevacizumab, oxaliplatin, and a fluoropyrimidine (RAISE): a randomised, double-blind, multicentre, phase 3 study. Lancet Oncol., 2015, 16(5), 499-508.

[34] Ellis, L. M., Bernstein, D. S., Voest, E. E., et al.: American Society of Clinical Oncology perspective: raising the bar for clinical trials by defining clinically meaningful outcomes. J. Clin. Oncol., $2014,32(12), 1277-1280$

[35] Yoshino, T., Yamazaki, K., Gotoh, M.: Safety and pharmacokinetics of second-line ramucirumab plus FOLFIRI in Japanese patients with metastatic colorectal carcinoma. Anticancer Res., 2015, 35(7), 4003-4007.

[36] Goldstein, D. A., El-Rayes, B. F.: Considering efficacy and cost, where does ramucirumab fit in the management of metastatic colorectal cancer? Oncologist, 2015, 20(9), 981-982.

[37] Mackey, J. R., Ramos-Vazquez, M., Lipatov, O., et al.: Primary results of ROSE/TRIO-12, a randomized placebo controlled phase III trial evaluating the addition of ramucirumab to firstline docetaxel chemotherapy in metastatic breast cancer. J. Clin. Oncol., 2015, 33(2), 141-148.

[38] Garcia, J. A., Hudes, G. R., Choneiri, T. K., et al.: A phase 2, single-arm study of ramucirumab in patients with metastatic renal cell carcinoma with disease progression on or intolerance to tyrosine kinase inhibitor therapy. Cancer, 2014, 120(11), 16471655 .

(Telekes András dr., Budapest, Maglódi út 89-91., 1106 e-mail: andras.telekes@bajcsy.hu) 